\title{
Hvernig verður „ríkisbangsinn flippaður“? List- og verkgreinakennarar á premur skólastigum segja rýnisögur úr starfendarannsóknum sínum
}

\author{
Svanborg R. Jónsdóttir og Hafdís Guðjónsdóttir \\ Abstract \\ - Um höfunda \\ About the authors \\ - Heimildir
}

Mikilvægi skapandi hugsunar og getu til skapandi athafna kemur skýrt fram í ákalli samtímans eftir nýsköpun og eru skapandi atvinnugreinar taldar vera mikilvægar í nútíma atvinnulífi. Samtíminn kallar sömuleiðis á sjálfbæra próun sem krefst hæfni til skapandi hugsunar og aðgerða til að geta leyst vandamál og komið til móts við margvíslegar og flóknar parfir heimsins. Menntastefna íslenskra yfirvalda frá 2011 byggir á sex grunnpáttum sem leggja skal til grundvallar allri grunnmenntun frá leikskóla til framhaldsskóla og einn peirra er sköpun. Hér er sagt frá starfendarannsókn átta list- og verkgreinakennara á grunn-, framhalds- og háskólaskólastigi í samstarfi við háskólakennara sem stýrði rannsókninni. Pátttakendur gerðu úttekt á kennslu sinni og kennsluháttum og greindu hvernig peir unnu að pví að efla hinn skapandi pátt í námi nemenda sinna. Gögnum var safnað á tímabilinu desember 2016 til nóvember 2018. Helstu gögn voru dagbókarfærslur um starfið, samráðs- og ígrundunarfundir, náms- og kennslugögn, viðtöl, safnmyndir (e. collage) og afurðir greiningaræfinga. Fyrstnefndi höfundur greinarinnar vann úr gögnunum sem allir höfðu sameiginlegan aðgang að og sá síðarnefndi var rýnivinur og tók pát í hluta rannsóknarvinnunnar. Við greiningu gagna var beitt nálgun frásagnarrýni og niðurstöðurnar settar fram sem rýnisögur. Niðurstöðum var skipað í tvo meginflokka: 1 . Að móta menningu skapandi náms og 2. Starfskenning og fagmennska. Nokkur pemu voru greind í hvorum flokki og eru pau kynnt með dæmum úr gögnunum sem rýnisögur kennaranna. Sú menning sem kennararnir leituðust við að móta einkenndist meðal annars af pví að kenna grunnvinnubrögð í bland við frelsi og sköpun, góðar kveikjur, tilraunir og skapandi samtöl. Með pátttöku í pessari rannsókn á eigin starfi sýndu kennararnir fagmennsku og metnað fyrir hönd sinnar greinar og kennarastarfsins. Peir sýndu hvernig hægt er að vinna hefðbundin verkefni eins og „ríkisbangsann“ á skapandi hátt um leið og pess er gætt að uppfylla kröfur aðalnámskrár.

Efnisorð: Sköpun, list- og verkgreinar, skapandi kennsluhættir, starfskenning, umgerð, atbeini, starfendarannsókn

Pessi grein er tileinkuð minningu Erlu Dísar Arnardóttur textílkennara sem lést fyrir aldur fram árið 2020. Hún var einn af pátttakendum rannsóknarinnar sem hér er lýst og er hennar minnst með pakklæti og söknuði. 


\section{Inngangur}

Færni til skapandi hugsunar og skapandi aðgerða hefur á síðustu áratugum verið viðurkennd sem mikilvægur hluti af almennri menntun (Craft, 2001a; NACCCE, 1999; OECD, 2019). Í opinberri orðræðu á Íslandi hefur á undanförnum áratug verið áberandi ákall eftir nýsköpun sem eigi meðal annars að stuðla að lausnum á vanda atvinnulífs og efnahagspróunar (Nýsköpun á Íslandi, 2018). Mikilvægi skapandi hugsunar og getu til skapandi athafna kemur skýrt fram í ákalli nútímans eftir nýsköpun og skapandi atvinnugreinar eru taldar vera fjórða víddin í atvinnuháttum nútíma samfélags (Ágúst Einarsson, 2012). Annað ákall samtímans um sjálfbæra próun parfnast pess líka að fólk hafi ræktað hæfileika sína til skapandi hugsunar og aðgerða til að geta leyst vandamál og komið til móts við margvíslegar og flóknar parfir heimsins og lífsins sem par prífst (Blake o.fl., 2013). Menntastefna íslenskra yfirvalda 2011 byggir á sex grunnpáttum sem leggja skal til grundvallar í allri grunnmenntun frá leikskóla til framhaldsskóla. Einn af peim er sköpun og er hann talinn lykilpáttur sem snertir og fléttast saman við hina grunnpættina á margvíslegan hátt. İ Aðalnámskrá grunnskóla 2011 segir m.a.: „Í sköpun felst að móta viðfangsefni og miðla peim, búa til, gera eitthvað nýtt eða öðruvísi en viðkomandi kann eða hefur gert áður“ (Mennta- og menningarmálaráðuneyti, 2012, bls. 24).

Sköpunarpátturinn á ekki aðeins við um kennslu í list- og verkgreinum heldur á hann að vera gegnumgangandi í öllu skólastarfi, eins og segir ía aalnámskrám, og sama gildir um Menntavísindasvið Háskóla Íslands. Kennsluhættir kennara í kennaramenntun purfa að einkennast meðal annars af pví að peir styðji við og efli skapandi færni kennaranema sem öðlast pekkingu og færni til að efla sköpun sinna nemenda, hvort heldur peir eru í leik-, grunn- eða framhaldsskóla. Á Menntavísindasviði Háskóla Íslands fór fram vinna á árunum 2012-2013 sem miðaði að pví að gera sköpun að sýnilegum og virkum hluta af öllu námi á sviðinu. Í kjölfar peirrar vinnu var Rannsóknarstofa um skapandi skólastarf á Menntavísindasviði stofnuð og stofan stóð fyrir starfendarannsókn kennara í hefðbundnum námsgreinum á fjórum skólastigum. Niðurstöður rannsóknarinnar sem kallast Rannsókn um skapandi skólastarf 1 (RASKA 1) hafa verið kynntar á ráðstefnum og birtust í greininni Narratives of creativity: How eight teachers on four school levels integrate creativity into teaching and learning (Svanborg R. Jónsdóttir, 2017).

List- og verkgreinar hafa lengstum verið taldar pær greinar sem efla sköpunarhæfni nemenda og pví var við hæfi að rýna einnig í hvernig kennarar pessara greina fara að pví að vinna með sköpun í kennslu sinni. Í seinni hluta rannsóknarinnar Rannsókn um skapandi skólastarf 2 (RASKA 2), sem hér er til umfjöllunar, voru fengnir pátttakendur úr hópi list- og verkgreinakennara á premur skólastigum til að gera starfendarannsókn. Rannsóknin fólst í að pátttakendur gerðu úttekt á kennslu sinni og kennsluháttum og greindu hvernig peir unnu að pví að efla hinn skapandi pátt í námi nemenda sinna. Slíkar rannsóknir efla kennarana sem taka pátt í henni auk pess sem niðurstöður tala til annarra kennara par sem pær eru unnar beint á „gólfinu“ (Zeichner, 1993).

Rannsóknarspurningin sem leitað var svara við í pessari rannsókn er: Hvernig vinn ég með sköpun í minni kennslu og hvaða tækifæri fá nemendur mínir til sköpunar í sínu námi?

\section{Fræðilegur bakgrunnur}

Hér verður fjallað um sköpunarhugtakið, kennsluhætti og stuðning við skapandi starf, tækni og áhrif rafrænna miðla á skapandi nám, og starfskenningu.

\section{Sköpun}

Sköpun er vi̊ðfeðmur páttur sem er hluti af allri tilveru okkar. Mörgum pykir hugtakið sköpun vera flókið og erfitt að skilgreina pað nákvæmlega. Pó eru til nokkrar ápekkar skilgreiningar á sköpun sem eru nokkuð víðar en pykja gagnlegar til að vinna út frá í kennslu. Skilgreining Sternberg og 
Lubart (1999) snýst um að líta á sköpunargáfuna (e. creativity) sem hæfileikann til að búa til (skapa eða framleiða) verk sem er bæði nýtt (frumlegt, óvænt) og viðeigandi (nýtilegt, mætir peirri pörf sem kallar á lausn).

Rannsóknir á sköpun á undanförnum fimm áratugum hafa próast frá pví að rannsaka aðallega einstaklinga sem eru afburðaskapandi yfir í að beina sjónum frekar að hinni almennu sköpunargáfu sem allir búa yfir (NACCCE, 1999). Slík sýn á sköpunargáfuna er samhljóða skilgreiningu Craft (2001a, 2001b) á litlu-s sköpunargáfunni, en hún er hluti af peirri hæfni sem nýtist í daglegu lífi til að bregðast við og leysa vandamál. Craft skilgreindi einnig kjarna skapandi hugsunar sem möguleikahugsun (e. possibility thinking) (Craft, 2000, 2001b; Craft o.fl., 2008; Jeffrey og Craft, 2006). Boðskapur námskránna frá 2011 um sköpun sem grunnpátt menntunar byggist á pessari sýn á að allir hafi getu til sköpunar og að pá hæfni sé hægt að rækta og skuli vinna með í öllu skólastarfi. Trú á eigin getu til sköpunar er mismunandi hjá einstaklingum en hana er hægt að rækta og efla (Chang o.fl., 2019; OECD, 2019; Tierney og Farmer, 2011) og pað er einmitt pað sem núgildandi námskrár boða að sé ekki aðeins mögulegt heldur beri að vinna að. Sá boðskapur birtist meðal annars í ritröð um grunnpætti menntunar, heftinu um sköpun par sem bent er á að hversdagsleg verk geti falið í sér sköpun, hvort sem pað er að stafla saltfiski eða baka smákökur (Ingibjörg Jóhannsdóttir o.fl., 2012). Par er einnig rökstutt að pjálfa megi fólk í skapandi hugsun og gagnrýnum vinnubrögðum, mikilvægt sé að leggja áherslu á að sköpun gegni lykilhlutverki í skólum landsins og að hún sé samtvinnuð öllu skólastarfi.

\section{Tækni og áhrif rafrænna miðla á skapandi nám}

Tæknipróun síðustu ára og áratuga hefur skapað fjölbreytta möguleika til náms og kennslu og hvata og stuðning til að ástunda skapandi vinnubrögð. Notkun stafrænna tóla til hönnunar hefur sýnt að pau geta eflt getu nemenda til sköpunar og aukið trú peirra á getu sína til sköpunar (Chang o.fl., 2019). Ein birtingarmynd skapandi skólastarfs í tengslum við tækni eru svokallaðar sköpunarsmiðjur (e. makerspaces) (Sólveig Jakobsdóttir o.fl., 2019). Rannsókn á fjórum tilvikum í tengslum við sköpunarsmiðjur sýndi mismunandi kennslufræðilega nálgun í framkvæmd smiðjanna (Kristín Dýrfjörð o.fl., 2019). Misjafnt var hvort kennslan var mjög kennarastýrð eða nemendamiðuð. Öll tilfellin endurspegluðu nálgun par sem leitast var við að nemendur hefðu svigrúm til að próa eigin hugmyndir og útfærslur í vinnu sinni. Rannsókn á viðhorfum frumkvöðla til notkunar tækni í leikskólakennslu sýndi að peir töldu að tæknin gæti eflt nám barna og lögðu áherslu á að nota hana á markvissan og skapandi hátt (Anna Elísa Hreiðarsdóttir, 2019). Viðhorf fjögurra myndmenntarkennara til notkunar snjalltækja í kennslu sýndu að peir sáu tækifæri til að breyta kennsluháttum sínum með pví að nýta snjalltæki markvisst við verkefni sem annars væru erfið í framkvæmd (Sigrî̉ur Ólafsdóttir o.fl., 2018).

\section{Kennsluhættir og stuðningur við skapandi starf}

Í ágætri leiðbeiningahandbók um skapandi skólastarf er bent á mikilvægi pess að beita fjölbreyttum kennsluaðferðum og vinnubrögðum til að styðja skapandi vinnu og vekja áhuga á námi (Sigrún Björk Cortes o.fl., 2016). Skapandi kennsluhættir og kennsla til sköpunar er m.a. talin geta veitt innblástur til að sjá námsefni og námsferli í nýju ljósi og ýta undir nám (Hrafnhildur Eiðsdóttir og Jóhanna Einarsdóttir, 2013). Skapandi samtöl (e. creative conversations) er einn páttur í mótun hugmynda sem styðja við og hvetja til sköpunar. Skapandi samtal felst í samræðum kennara og nemanda eða milli nemenda par sem ein hugmynd kveikir aðra. Samtalið verður skapandi ferli par sem framlag peirra sem taka pátt í pví örvar próun hugmyndar (Svanborg R. Jónsdóttir, 2011). Eitt einkenni skapandi kennsluhátta er nemendamiðað nám sem byggir á að nemendur hafi umtalsverð áhrif á nám sitt (Ásta Henriksen, 2018; Collard og Looney, 2014; Lucas o.fl., 2013; Svanborg R. Jónsdóttir og Rósa Gunnarsdóttir, 2017). Рað pýðir gjarnan að kennarinn tekur sér stöðu sem leiðbeinandi á hliðarlínunni frekar en stjórnandi og styður nemandann til að verða skapandi og sjálfstæður í námi sínu og sköpun (Craft o.fl., 2012; Svanborg R. Jónsdóttir og M. Allyson Macdonald, 2019). Sumum 
kennurum finnst erfitt að leyfa sveigjanleika og frelsi og kjósa að hafa stífa stjórn í kennslunni. Peir óttast að missa stjórnina, tilfinningin hefur verið kölluð „óttinn við óreiðuna“ (e. chaos angst) og er ekki alltaf meðvituð (Svanborg R. Jónsdóttir, 2017; Svanborg R. Jónsdóttir og M. Allyson Macdonald, 2019). Viðhorf kennara og pað að vera meðvitaður um starfskenningu sína eru mikilvægir pættir sem styðja skapandi kennslu og kennslu til sköpunar (Svanborg R. Jónsdóttir, 2017; Svanborg R. Jónsdóttir og Rósa Gunnarsdóttir, 2017).

\section{Starfskenning}

Allt sem kennarar gera og vilja gera byggir á ákveðinni starfskenningu (e. practical theory) en er persónuleg kenning sem próast með aukinni pekkingu og reynslu en er oft ómeðvituð (Hafdís Guðjónsdóttir, 2004; Handal og Lauvås, 1987). Starfskenning fléttast saman úr fræðilegri pekkingu kennarans, reynslu, siðferðilegum gildum og ígrundun um eigið starf (Hafdís Ingvarsdóttir, 2004). Starfskenning byggir meðal annars á pekkingu kennara á kennsluefni, kennslufræðum, markmiðum kennslu í námskrám, viðhorfum til nemenda og tilfinninga peirra, eigin persónulegum gildum og öðru sem tengist starfinu. Með pví að gera starfskenningu sína meðvitaða geta kennarar gert sér grein fyrir hvers vegna peir velja ákveðnar aðferðir í kennslu, styrkja starfspróun sína og eflast sem fagmenn (Dalmau og Hafdís Guðjónsdóttir, 2017). Fagleg ígrundun eins og felst í að gera starfendarannsókn er virkt ferli sem getur veitt kennurum dýpri skilning og leitt til betra og markvissara starfs (Loughran, 2002). Kennarar í list- og verkgreinum geta verið fyrirmyndir um skapandi kennsluhætti en purfa ekki síður en aðrir fagmenn að pekkja pá áhrifapætti sem stýra peim leynt og ljóst, par á meðal að átta sig á starfskenningu sinni.

\section{Аðferðafræði og aðferð}

Starfendarannsóknasnið hentar vel meginmarkmiði rannsóknarverkefnisins sem var að varpa ljósi á hvaða leiðir list- og verkgreinakennarar á premur skólastigum fara til að efla sköpun í kennslu sinni og námi nemenda. Niðurstöður rannsóknarinnar geta verið öðrum kennurum leiðarljós um leið og rannsóknarferlið hafði áhrif á kennslu pátttakendanna.

Margir pættir einkenna góðar starfendarannsóknir kennara en áberandi er einlægur vilji til að bæta menntun (Zeichner, 1993). Kennarinn hefur pann ásetning að rannsaka viðfangsefni sem hjálpar honum að vinna með pað á áhrifaríkari hátt en áður og virkja hinn margpætta veruleika kennslustofunnar (Stringer, 2007). Leitast er við að lýsa, túlka og skýra ferli eða atburði sem eiga sér stað í menntastofnunum á sama tíma og reynt er að bæta viðkomandi ferli (McNiff, 2017; McNiff o.fl., 2003). Aðgerðir til úrbóta eru vandlega ígrundaðar breytingar sem byggja á upplýsingum sem safnað er í rannsóknarferlinu auk fyrri rannsókna um sams konar viðfangsefni (Hafdís Guðjónsdóttir, 2004). Áhersla er lögð á að birta niðurstöður, ekki aðeins á eigin vinnustað par sem pær koma beint að gagni heldur einnig par sem pær eru aðgengilegar öðrum, á innlendum og alpjóðlegum vettvangi, á ráđstefnum og í tímaritum. Rannsakandinn er miðpunktur starfendarannsóknarinnar og peirra aðgerða sem skoðaðar eru og framkvæmdar sem hluti af rannsóknar- og próunarferli (Feldman, 2002; Hafpór Guðjónsson, 2011). Kennararnir sem tóku pátt í rannsókninni voru pannig bæði rannsakendur og peir sem voru rannsakaðir, bæði störf peirra og eigin hugmyndir um kennslu.

\section{Pátttakendur}

Í pessari rannsókn tóku pátt átta list- og verkgreinakennarar á premur skólastigum auk stjórnanda rannsóknarinnar. Pátttakendur voru valdir út frá ábendingum um öfluga list- og verkgreinakennara:

Guðrún Gísladóttir myndlistarkennari í Vogaskóla

Erla Dís Arnardóttir textílkennari í Háaleitisskóla 
Kristín Garðarsdóttir textílkennari í Víðistaðaskóla

Sverrir Marinó Jónsson upplýsingatækni- og smíðakennari í Grunnskóla Vestmannaeyja

Engilbert Imsland nýsköpunar- og smíđakennari î Hólabrekkuskóla

Jóhanna Jakobsdóttir myndlistarkennari í Framhaldsskólanum í Mosfellsbæ

Guðrún Halldóra Sigurðardóttir myndlistarkennari í Fjölbrautaskólanum í Breiðholti

Ása Helga Ragnarsdóttir leiklistarkennari og aðjúnkt við Menntavísindasvið

Svanborg R. Jónsdóttir prófessor við Menntavísindasvið sem leiddi vinnu rannsóknarhópsins og er fyrstnefndi höfundur greinarinnar.

Hafdís Guðjónsdóttir prófessor á Menntavísindasviði, annar höfundur greinarinnar kom inn í vinnu með rannsóknarhópnum, var rýnivinur á seinni stigum greiningarvinnu og við skrif greinarinnar.

\section{Gögn}

Gögnum var safnað á tímabilinu desember 2016 til nóvember 2018. Gagnaöflun fólst í eftirfarandi:

1. Dagbækur. Kennarar skráðu dagbókarfærslur um kennslu sína með sérstakri áherslu á pætti sem fólu í sér sköpun, skapandi kennsluhætti og tækifæri nemenda til sköpunar.

2. Hver kennari safnaði öðrum gögnum að eigin vali, m.a. kennslulýsingum, skipulagi námseininga, skólanámskrá, bekkjarnámskrá og verkefnum nemenda.

3. Samstarfs- og ígrundunarfundir pátttakenda voru haldnir einu sinni í mánuði í tvo klukkutíma í senn og voru teknir upp og afritaðir. Par var fjallað um skráningar kennaranna, sagðar sögur úr starfinu, rætt um áskoranir og ávinning af list- og verkgreinakennslu og hvernig kennararnir unnu að pví að efla sköpun nemenda sinna.

4. Hver kennari tók viðtal við annan kennara í rannsókninni, afritaði og skilaði handriti sem var greint sem hluti af gögnum.

5. Safnmyndir (e. collage). Á einum fundinum gerðu kennararnir safnmynd sem peir bjuggu til úr klippimyndum úr tímaritum og blöðum. Myndin átti að tákna starfskenningu peirra, útlistun á hvernig kennarar peir vildu vera. Peir túlkuðu myndina á staðnum og útskýrðu hvernig mætti lesa úr henni.

6. Greiningaræfing. Hver kennari tók fyrir ákveðinn hluta kennslu sinnar og gerði greiningu á framkvæmd hennar út frá hugtökum um umgerð í kennslu og námi.

Greining kennaranna byggði á hugtakinu umgerð (e. framing) sem Bernstein (2000) skilgreindi og snýst um hver stýrir og stjórnar í kennslu og námi. Pví tengt er hugtakið flokkun (e. classification) sem sýnir hversu aðgreind hlutverk nemanda og kennara eru. Athygli kennaranna beindist gjarnan að pví að greina í sínum gögnum hversu mikil stýring peirra og stjórnun væri í kennslunni, hversu mikinn atbeina (e. agency) peir gæfu nemendum og frelsi til eigin sköpunar.

Eftir að gagnaöflun lauk formlega lágu fyrir sameiginleg gögn sem safnast höfðu í pessu tveggja ára ferli. Pau samanstóðu af 250 blaðsíðum af afritun funda hópsins, nokkrum tugum blaðsíðna af efni frá kennurunum og myndrænni tjáningu um eigin starfskenningu í safnmyndum. 


\section{Rannsóknarferlið, greining og framsetning niðurstaðna}

Rannsóknarferli af pessu tagi er ekki línulegt en í pví skiptast á skref sem eru endurtekin nokkrum sinnum og mynda eins konar spíralferli (McNiff, 2017). Ferlið hófst á pví að pátttakendur ígrunduðu og lögðu mat á starfshætti sína og drógu fram pær áherslur sem rannsóknin beindist að (p.e. sköpun). Næsta skref var að safna gögnum, pau voru greind og metin jafnóðum og starfshættir endurskipulagðir í kjölfar matsins. Kennararnir söfnuðu gögnum um eigið starf og mátuðu nálganir sínar í kennslu við aðalnámskrá, kröfur um námsmat, sköpunarheftið (Ingibjörg Jóhannsdóttir o.fl., 2012) og fræðileg líkön um skapandi kennslu og nám.

Greining gagna fór fram með nálgun frásagnarrýni (e. narrative inquiry) og niðurstöðurnar voru settar fram sem rýnisögur (e. narratives) (Connelly og Clandinin, 1990; Kim, 2015). Sögurnar sýna dæmi um viðfangsefni sem lýsa vel hvernig kennararnir vinna að pví að efla sköpun nemenda sinna í list- og verkgreinum og hvernig peir skilja viðfangsefni sitt. Frásagnarrýni er aðferð til að rannsaka hvernig manneskjan upplifir hina mannlegu tilveru og eru niðurstöður settar fram sem sögur par sem reynslan er endurskrifuð og túlkuð (Connelly og Clandinin, 1999; Kim, 2015). Aðferðin pykir henta vel til að gefa kennurum tækifæri til að segja frá og útskýra kennslu sína og reynslu (Lilja M. Jónsdóttir, 2012). Kennarinn fær „rödd“ með pví að segja sögu sína og vald til að skilgreina eigið starf. Pað felur í sér pá valdeflingu sem einkennir starfendarannsóknir (Edda Kjartansdóttir, 2010).

Til pess að koma reynslu og sögum kennaranna á framfæri tók ég (fyrstnefndi höfundur greinarinnar) að mér að greina pau gögn sem lágu fyrir í sameiginlegu gagnasafni og segi frá í fyrstu persónu eintölu. Dagbækur kennaranna voru peirra eigin og studdu við frásagnir peirra á fundum. Ég marglas gögnin, beitti í fyrstu yfirlestrum aðleiðsluaðferðum og leitaði að merkjum um skapandi kennslu, áskoranir og annað sem kallaði á athygli mína. Ég leitaði merkja um hvar kennararnir voru stýrandi, hvar peir ýttu undir atbeina nemenda sinna og hvar peir gáfu frelsi til sköpunar. Ég bar niðurstöðurnar undir rýnivin sem er annar höfundur greinarinnar og ræddi pá flokka og pemu sem ég hafði greint. Með sögum kennaranna er dreginn fram skilningur peirra, lærdómur af rannsóknarferlinu í tengslum við sköpunarhugtakið og hvernig peir upplifa sig sem list- og verkgreinakennara sem leitast við að efla sköpun nemenda sinna.

\section{Niðurstöður}

Niðurstöður voru að lokum flokkaðar í tvo meginflokka: 1. Að móta menningu skapandi náms, 2. Starfskenning og fagmennska. Nokkur pemu voru greind í hvorum flokki og verða pau kynnt með dæmum úr gögnunum sem rýnisögur kennaranna. Í hvorum flokki eru aðeins tilgreind valin dæmi úr gögnunum sem best lýsa hverju pema.

\section{Að móta menningu skapandi náms}

Í gögnunum kom fram að kennararnir leituðust við að móta ákveðna menningu í kennslu sinni, menningu skapandi náms. Ein leiðin sem peir völdu var að losa um umgerð kennslunnar og gefa nemendum aukinn atbeina, sem fólst í meira frelsi sem kennurunum fannst oft togast á við kröfur námskrárinnar. Peir lögðu pó líka áherslu á að nota góðar kveikjur og að vera óhræddir við að gera tilraunir, bæði peir sem kennarar og hvetja nemendur til pess. Einnig kom fram að rými til skapandi samtala milli kennara og nemenda væri góð leið til að styðja við og efla sköpun nemenda.

\section{Átök milli krafna námskrár, frelsis og sköpunar}

Kennararnir röktu í sögunum hvernig peir fóru að pví að kenna greinina sína og hvöttu á sama tíma til sköpunar og studdu við hana í vinnu nemenda. Peir töluðu um að námskráin og markmið námsgreinarinnar bæru í sér mikla stýringu sem fælist í að nemendur tileinkuðu sér ákveðin vinnubrögð og pekkingu áður en peir fengju að vera frjálsir og skapandi. Við ræddum um petta tog milli krafna um verkfærni og frelsis til sköpunar og Guðrún Gísladóttir myndlistarkennari velti pessu upp varðandi sína kennslu: 
Ég er svolítið upptekin af hindrununum. Mínum eigin hindrunum og hvort ég vel verkefni sem stuðla að sköpun eða verkefni sem hindra sköpun. Svo fór ég að hugsa um aðalnámskrána. Einn grunnpáttur menntunar er sköpun og svo eru hæfniviðmið við lok 4., 7. og 10. bekkjar. Ef ég á að geta uppfyllt pessi hæfniviðmið pá parf ég að kenna pessa og alls konar færni. Geta valdið verkfærum, aðferðum, yrt verkefnin sín, sagt frá peim og allt pað. Tekst mér petta og líka að hafa verkefnin pað opin að sköpunin sé meira frá peim en að aðalnámskráin stjórni peim? Stundum finnst mér ég vera í limbói parna á milli, mér líður stundum bara ekkert vel með pað.

Vinnan við starfendarannsóknina gerði pau meðvituð um pessi átök og pau ræddu hvernig pau gætu unnið markvisst með pau. Kristín textílkennari velti fyrir sér:

Já en líka, petta fær mann líka til pess að spyrja sjálfan sig hvað er sköpun? Er ég alltaf bara að kenna færnina, er ég aldrei að leyfa peim að prófa eitthvað, en ég vil að pau fái alltaf eitthvað að velja eitthvað og svo pegar pau eru búin með skylduverkefnið að velja eitthvað plús.

Parna má sjá glímuna við að kenna bæði tiltekna færni en leyfa líka að vinna frjálst, minna stýrt og pá meira skapandi. Nemendur eru oft ópolinmóðir og vilja komast í að vinna sjálft verkefnið en ekki undirbúningsferlið. Erla Dís textílkennari lýsti ákveðnu ferli í kennslu í fatahönnunarvali:

Við byrjum á að taka myndir og svo gerum við úrklippur og svo teiknum við, ég kenni peim tískuteikningu og pær eru bara: „Ohh, hvenær fæ ég að sauma kjólinn?“" Hugmyndin er ekki komin pannig að pað er pað erfiðasta sem ég glími við, að fá pær með mér í ferlið.

Kennararnir í rannsóknarhópnum voru sammála um að pað væri hægt að gera hvort tveggja, eins og Jóhanna myndlistarkennari benti á: „Pað er alveg hægt að blanda pví saman.“

Talsvert var rætt um hvernig ákveðin hefðbundin verkefni hefðu tilhneigingu til að stýra kennslu í list- og verkgreinum, afurðirnar yrðu oft mjög svipaðar og litla sköpun að sjá í peim. Pessi verkefni væru gjarnan tengd ákveðnum markmiðum námskrár og væru pess vegna góð frá pví sjónarmiði að uppfylla kröfur námskrár fyrir ákveðinn aldur. Erla Dís textílkennari ræddi um pessa áskorun um að ýta undir sköpun nemenda en halda samt í hefðbundið skylduverkefni sem hún kallaði „ríkisbangsann":

Eins og með bangsann. Í fyrra var ég með alveg frjálst. Рað var allt í gangi og pað var gaman en pað var hell. En nú er ég með aðeins öðruvísi, ég er með snið, en ég læt pau breyta honum pínulítið. Læt pau gera hann að sínum. Pið vitið parna ríkisbangsann sem ég hata. Ég er alveg ok: „Фið verðið að gera hann að ykkar. Ef hann er of líkur ríkisbangsanum, skammast ég mín,“ og er alveg: „Nei, nei, petta fer ekki út úr minni stofu.“ En ég vil að petta sé skapandi og ég vil að petta sé skemmtilegt og að hann geti jafnvel orðið svolítið flippaður.

Pannig fann hún leið til að nýta hefðbundið verkefni svo að pað yrði skapandi með pví að leggja áherslu á sköpunarpáttinn auk peirrar tækni og færni sem nemendur tileinkuðu sér í ferlinu. Ljóst var að formlega námskráin hafði mikil áhrif á starf kennaranna í list- og verkgreinum og að hún togaði pá stundum í gagnstæðar áttir. Greinilega er áskorun að finna jafnvægi milli pess að kenna ákveðna færni og að veita frelsi til sköpunar.

Pegar kennararnir höfðu ígrundað hvernig umgerð peir voru almennt með í kennslunni lýstu peir yfir að peir myndu vilja losa um stýringu til að gefa nemendum meira svigrúm til sköpunar.

\section{Losa um umgerð - veita nemendum aukið frelsi til sköpunar}

Kennararnir ræddu á fundunum um að peir vildu losa meira um umgerðina í kennslu sinni til að auka frelsi nemenda til sköpunar. Ása leiklistarkennari sagðist stundum finna óöryggi hjá sínum 
nemendum pegar peir ættu að skila verkefnum sem hún gæfi peim frelsi til að útfæra eftir eigin höfði. Jóhanna myndlistarkennari byrjar gjarnan með sínum nemendum á að vinna óhlutbundin myndverk, hvetur pá til að binda sig ekki við neitt sérstakt og peir mega jafnvel fara út með vinnuna:

... byrjuðu með abstrakt .. pau eru með eitthvað, já engar línur og ekki neitt og sem sagt fóru með alls konar liti og bleyttu blöðin og fóru með petta út og skvettu og ég var bara alltaf með moppuna bara á eftir peim.

Kristín textílkennari vekur áhuga nemenda með pví að gefa peim vald yfir ýmsum páttum. Til dæmis útvíkkar hún námsefni með pví að leyfa nemendum að leita í Internetið svo peir geti fundið par eitthvað sem höfðar til peirra. Hún hvetur pá til að vera skapandi í að nýta uppskriftir:

Ég spyr nemandann kannski: „Langar pig að breyta uppskriftinni? Pú parft ekki að fara eftir bókinni, pú mátt gera annað eða gera petta öðruvísi. Geturðu séð petta einhvern veginn öðruvísi fyrir pér og ef pú teiknar pað upp og geturðu pá heklað eftir myndinni?“"

Hún ýtir pannig undir áhuga og eignun (e. ownership) á verkefnunum og hvetur nemendur til að beita möguleikahugsun. Kristín leyfir peim líka gjarnan að ráða staðsetningu sinni í stofunni og hvort peir vilji standa eða sitja við að vinna. Sverrir upplýsingatækni- og smíðakennari lýsti frjálslegum reglum um samskipti og staðsetningu innan kennslustofunnar sem hann kennir í:

Í tölvustofunni, pau labba um og sjá hvað hinir eru að gera. ... En petta er bara hjá mér. Og eins í smíðastofunni, ég vil frekar að pau geri petta, tali saman og fái pannig hugmyndir. Alveg eins og við erum að gera hérna, við erum að tala saman og fá hugmyndir. Petta kallar líka á góða samvinnu. Mér finnst ekkert óeðlilegt að pau standi upp og spjalli saman, en bara að pað séu ekki læti.

Lýsingin gefur til kynna nokkuð lausa umgerð um pessa tvo pætti hjá honum en hann segir jafnframt að pessar reglur gildi hjá honum en ekki öðrum kennurum. Dví kann að vera að nemendur purfi að tileinka sér annars konar félagslegt læsi en pað sem peir eru vanir og purfi að læra aðrar reglur en almennt gilda innan skólans. Âlykta má að oft sé sérstök menning sem tilheyri list- og verkgreinunum, menning sem ætlað er að rækta hinn skapandi pátt í nemendum.

\section{Kveikjur}

Allir kennararnir í rannsókninni komu inn á mikilvægi pess að vera með áhrifaríkar kveikjur til að vekja áhuga og virkja nemendur í upphafi tíma eða verkefnis. Erla Dís textílkennari deildi með okkur hvernig hún fór að:

Fyrst einmitt sýndi ég peim kannski of lítið. Ég sýndi peim fá mynstur, kannski ógeðslega einföld, sagði peim ekkert rosalega mikið frá mér. Pað hjálpar að sýna peim pað sem ég geri, sýna peim að petta er pað sem ég vinn við og mér finnst pað rosa gaman og er með náttúrulega bara hreina ástríðu fyrir pessu.

Parna leggur Erla Dís áherslu á að vanda upphaf verkefnanna og að kennarinn sýni ástríðu fyrir pví sem verið er að kenna.

Kristín textílkennari nefndi að pegar hún vildi að nemendur hönnuðu sjálfir eitthvað pá væri ekki nóg að setja blað fyrir framan pá og segja „teiknaðu petta“ en „... ég geri pað pá oft að sýna peim myndir og hugmyndir, einhver dæmi og pá kviknar oftast eitthvað hjá peim“. Jóhanna myndlistarkennari ræddi líka mikilvægi góðra kveikja: „Að pær séu sterkar, að pær séu dulúðugar, að pað sé eitthvað spennandi að koma fram." Erla Dís textílkennari notar hraðskissuaðferð sem hún lærði í listnámi sínu, bæði sem kveikju og líka til að leggja áherslu á að ekkert sé vitlaust sem kemur frá hjartanu. Hún sagðist ítrekað endurtaka pau skilaboð: „Рað er ekkert vitlaust, pað er ekkert ljótt, pað er ekkert fallegt - gerið bara pað sem kemur frá hjartanu, látið bara blýantinn fara sína leið.“ 
Parna má sjá dæmi um hvernig kennararnir leitast við að móta ákveðna menningu, menningu sem losar um hömlur og skapar viðhorf um að engar afurðir séu ljótar. Slíkri menningu hafa peir kynnst í námi sínu og reyna að endurskapa í sinni kennslu. Kennararnir ræddu á fundunum um mikilvægi pess að vera meðvitaðir um og gera nemendur líka meðvitaða um að kveikjur, fyrirmyndir og hugmyndir frá öðrum ættu ekki að vera til að afrita eða taka upp lítið breytt heldur fyrst og fremst til að kveikja áhuga og hvetja til eigin sköpunar.

\section{Skapandi samtöl}

Eitt af pví sem virtist einkenna vinnusmiðjuandrúmsloft og skapandi menningu sem kennararnir leituðust við að laða fram voru skapandi samtöl, ýmist milli kennara og nemenda eða milli nemenda. Erla Dís textílkennari sá slík samtöl eiga sér stað reglulega. Í eitt skipti sagði hún sögu af vinnu sem snerist um að sauma refil:

Ég setti java yfir stórt borð og pau sitja í hring alveg tólf og pað gerist alltaf eitthvað áhugavert - pað verður alltaf eitthvað samtal á milli peirra og samtalið virðist ýta undir einhverja sköpun meðal peirra án pess að ég væri að grípa inn í, ég var búin að veita peim rammann, vinnuaðferðirnar og ég var svolítið á hliðarlínunni, en samt náttúrulega аð аðstoða.

Hún sagðist hafa unnið með fleiri álíka verkefni um veturinn og séð skapandi samtöl eiga sér stað:

Bæði par sem pau eru að prjóna saman og pá einhvern veginn fara pau að ræða pað sem pau eru að gera. Pá eru pau svolítið í núvitund og ef við gerum petta einmitt kveikir pað möguleikahugsun. Pá ertu komin með tvo aðila eða jafnvel fleiri að brainstorma, bara alvöru eins og listamenn gera, pað verður einhver alvöru vinna og pað verður alvöru dýnamík finnst mér í verkefnunum og pau eiga pað líka saman.

Parna varð hún vör við petta vinnusmiðjuandrúmsloft og sá vinnubrögð hjá nemendum sínum sem hún hafði sjálf kynnst í sínu listnámi. Guðrún Gísladóttir myndlistarkennari lýsti dæmi par sem hún heyrði skapandi samtöl milli nemenda í líflegum hópi í öðrum bekk sem unnu verkefni um fugla:

Ég fann petta og ég held að pau hafi fundið petta og petta vakti ánægjulega tilfinningu inn í mér, ekki síður en peim, fannst mér ég upplifa. Pau sátu saman við borð, hvert á móti öðru, gátu talað saman, kveikt hugmyndir hvert hjá öðru og bjuggu til sögurnar saman, meðan pau hentu á milli sín hugmyndum ... pau duttu inn í einhvern leik, einhverja sögu, í gegnum eitthvað samtal sín á milli.

Parna hafði Guðrún gefið peim tækifæri til að vinna frjálst í upphafi, leika sér, tala frjálst og ráða ferðinni áður en pau tjáðu sig myndrænt. Svigrúmið sem hún skapaði parna fyrir sköpunarkraft nemenda sinna líkti hún við „makerspace“ eða sköpunarsmiðju og hún bætti við: „Detta var eins og huglægt eða andlegt makerspace.“

\section{Tilraunir}

Hjá kennurunum kom fram að tilraunavinna, að fikta og prófa eitthvað nýtt skipti máli til að hvetja til sköpunar. Guðrún Gísladóttir myndlistarkennari lýsti vinnu sem kennaranemar voru með hjá henni î myndmennt hjá fjórða og fimmta bekk:

Báðir pessir aldurshópar voru svo tilbúin í að skapa í gegnum leik og skapa í gegnum tilraunir án pess að purfa að vita endilega hvað kæmi út úr pví og mér fannst pað bara ótrúlega inspiring fyrir mig sem kennara líka af pví að maður er oft svo fókuseraður á lokaafurð ... petta var bara leikur og tilraunir og pað sem kom út var frábært.

Engilbert, nýsköpunar- og smíðakennari, benti á að til pess að ýta undir sköpun nemenda pyrfti kennarinn að vera til í að gera tilraunir og að hvetja nemendur til að gera tilraunir sem byggðu á að 
beita peim tólum og tækjum sem peir ættu að læra á. Erla Dís textílkennari ræddi líka um að pó hún passaði að kenna pá tækni sem ætlast væri til pá legði hún líka áherslu á að prófa nýja hluti, breyta til og gera tilraunir:

Ég vil kenna peim tækni og ég vil kenna peim líka samvinnu og samstarf og pað hvernig ólíkir einstaklingar geta búið til svo ótrúlega töfra saman en kannski ekki einn og einn og einn og pað er svolítið pannig sem ég vinn. Ég er búin að pæla rosa mikið í pessu og vera mjög upptekin af pví að prófa verkefni. Pó ég sé frekar ný pá er ég mjög mikið að breyta og gera tilraunir, ég er ekki hrædd við pað, sem er held ég jákvætt vonandi.

Hún benti á pessa skapandi töfra sem yrðu til í samvinnu ólíkra einstaklinga og kveiktu nýjar og spennandi hugmyndir, sem gerðist síður pegar einstaklingarnir ynnu einn og einn.

Kennararnir lögðu ríka áherslu á að nemendur peirra gerðu tilraunir og prófuðu sig áfram. Erla Dís textílkennari sagði um unglingahópinn sem hún kenndi: „Pau voru í alls konar tilraunum, búin að prófa alls konar aðferðir í textíl, búin að fara út og suður, vinna hugmyndavinnu eins og alvöru listamenn." Hún kunni að meta vinnu nemenda sem sýndu slíkt por. Por og kjarkur og vilji til að prófa og reyna á sig skipti máli í kennslunni og var hluti af pví andrúmslofti sem kennararnir leituðust við að leggja áherslu á.

\section{Starfskenning og fagmennska}

Рað kom ítrekað fram að kennurunum fannst gagnlegt að taka pátt í rannsókninni og að pað efldi pá sem fagmenn. Ég var ekki búin að vinna lengi með kennurunum pegar ég gerði mér grein fyrir að allir voru peir sterkir fagmenn og bjuggu yfir starfskenningu sem var peim misjafnlega meðvituð.

\section{Starfskenning list- og verkgreinakennara}

Ákveðin merki um starfskenningu kennaranna mátti greina á fundunum sjálfum í frásögnum peirra og tjáningu. Einnig drógu viðtölin sem pau tóku hvert við annað skýrt fram hvað pau vildu standa fyrir sem kennarar, sem og myndræna tjáningin í safnmyndinni sem pau gerðu á einum fundinum. Sameiginlegir pættir sem komu fram í starfskenningum kennaranna voru:

- Stöðug viðleitni til að bæta sig í starfi

- Vilji og löngun til samstarfs við aðra kennara

- Afla sér trausts og sýna nemendum virðingu

- Pora og prófa

- Nálgast nemendur á peirra forsendum

- Styðja nemendur til að vera meðvitaðir um tilfinningar sínar til að ýta undir tjáningu og sköpun

- Nýta rafræn tól og tæki

- Fjölbreyttar kennsluaðferðir, fölbreytt efni og fjölbreytt verkefni

- Leiðbeinandi og uppörvandi án pess að vera dæmandi

- Ýta við nemendum og hvetja

- Pjálfa grunnvinnubrögð samhliða skapandi vinnu

- Öflugar kveikjur

- Vera opinn fyrir hugmyndum nemenda

Sverrir upplýsingatækni- og smíðakennari sagðist leggja áherslu á að vinna með öðrum kennurum í skólanum. Hann legði líka áherslu á að vera stöðugt að bæta sig í starfi. Ása leiklistarkennari sagði að henni pætti mikilvægast að byggja kennsluna á trausti og virðingu og að sýna nemendum umhyggju til að byggja upp sjálfsmynd peirra. Hún vildi líka gjarnan ýta undir skapandi og gagnrýna hugsun og að viðhafa gleði og kímni í kennslunni. Engilbert nýsköpunar- og smíðakennari lagði áherslu á að 
vera heiðarlegur, vera hann sjálfur, leika sér og beita leiklist og umbera ákveðinn óróa og fyrirferð í nemendum. Jóhönnu myndlistarkennara fannst mikilvægt að nemendur hennar í myndlistaráföngum væru meðvitaðir um tilfinningar sínar og áttuðu sig á peim til að opna frekar fyrir tjáningu peirra og sköpun.

Kristín textílkennari lýsti starfskenningu sinni pannig að hún vildi ýta við nemendum og hjálpa peim að verða betri í að vinna með textíl en peir voru áður. Hún sagðist purfa að finna út hvað hentaði hverjum og hún reyndi að gera nemendur meðvitaða um að textílmennt væri mikilvæg grein.

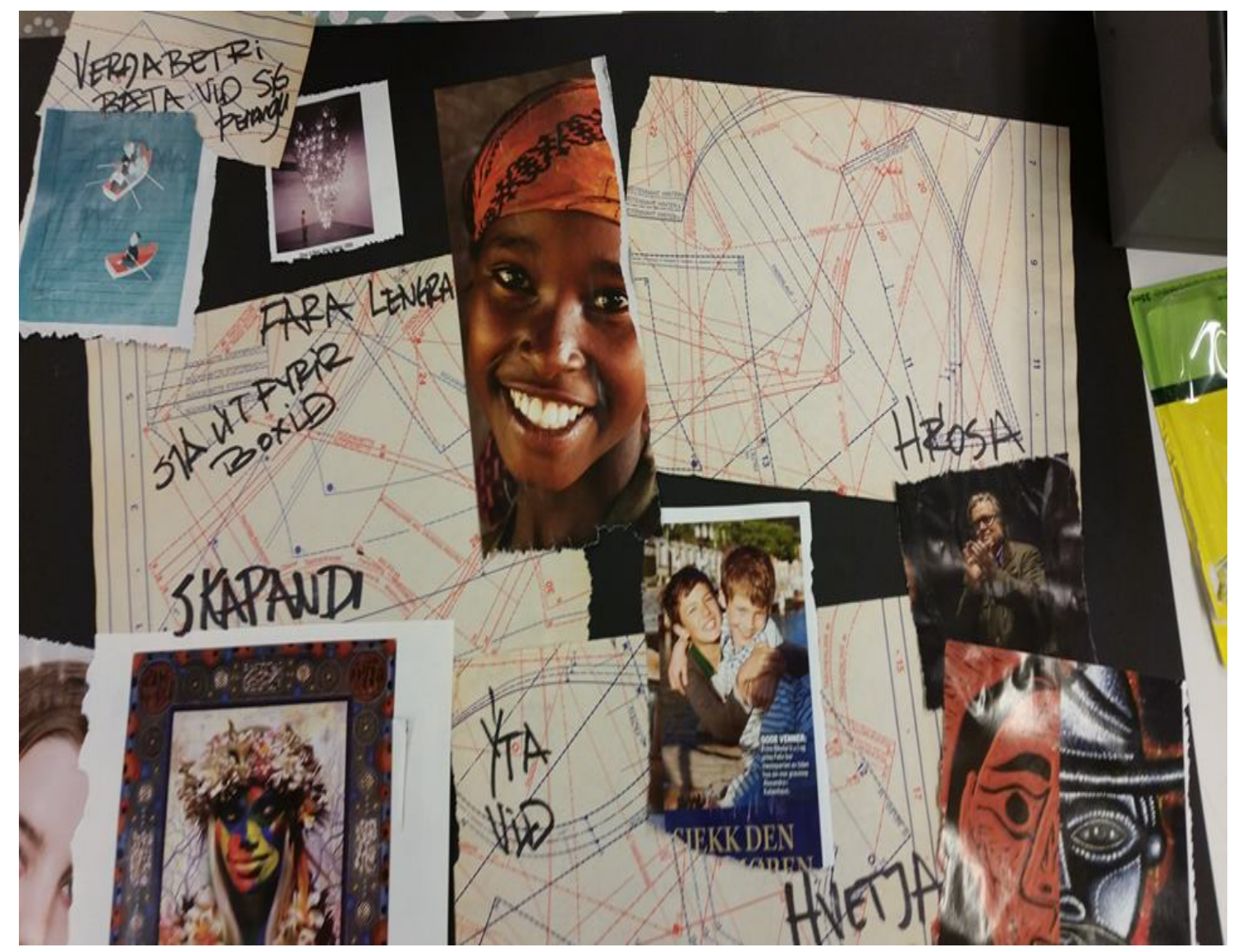

Mynd 1. Safnmynd Kristínar - starfskenning.

Pegar Kristín lýsti safnmyndinni (mynd 1) sem táknaði starfskenningu hennar sagðist hún vilja vera kennari sem hreyfði við nemendum og ýtti við peim:

Ég parf ekkert að vera vinsæll kennari - bara kannski frekar kennari sem skilur eitthvað eftir.

Maður parf eiginlega að kynnast nemendunum og finna út hvað hentar peim og hvernig maður á að tala við pá, hvað parf maður að útskýra mikið og parf maður að vera hvetjandi og ýta.

Ég reyni bara að spjalla aðeins við pau. Finna út hvort pað er eitthvað annað sem gæti hentað peim betur. Og svo kem ég með ástæður fyrir pví að nota textíl að og textílmennt sé alveg jafn mikilvæg og önnur fög.

Hún sagði að pað skipti sig máli að sjá ánægða nemendur „... sjá pau ánægð með verkefnin sín. Koma glöð inn og fara glöð út“. Pegar hún fyndi að nemendurnir væru ánægðir „... pá finn ég alveg að ég er að gera góða hluti, pá er pað kannski alveg nóg“. 
Guðrún Halldóra myndlistarkennari sagði að yfirleitt væru ekki agavandamál í hennar kennslu, sem er á framhaldsskólastiginu. Pó kæmi fyrir að einn og einn nemandi væri ekki að vinna neitt. Pá sagðist hún reyna að tengjast nemandanum og spjalla við hann:

Vinskapur finnst mér skipta miklu máli, að pau upplifi mann ekki sem ógn heldur tengja við mann og slaki á. Í skapandi vinnu er svo mikilvægt að maður sé ekki undir neinum járnhæl heldur að manni finnist maður geti gert hvað sem er. Alveg sama hvort pað er gott eða slæmt, aðalatriðið er að gera tilraunir, pví fleiri tilraunir, pví betra.

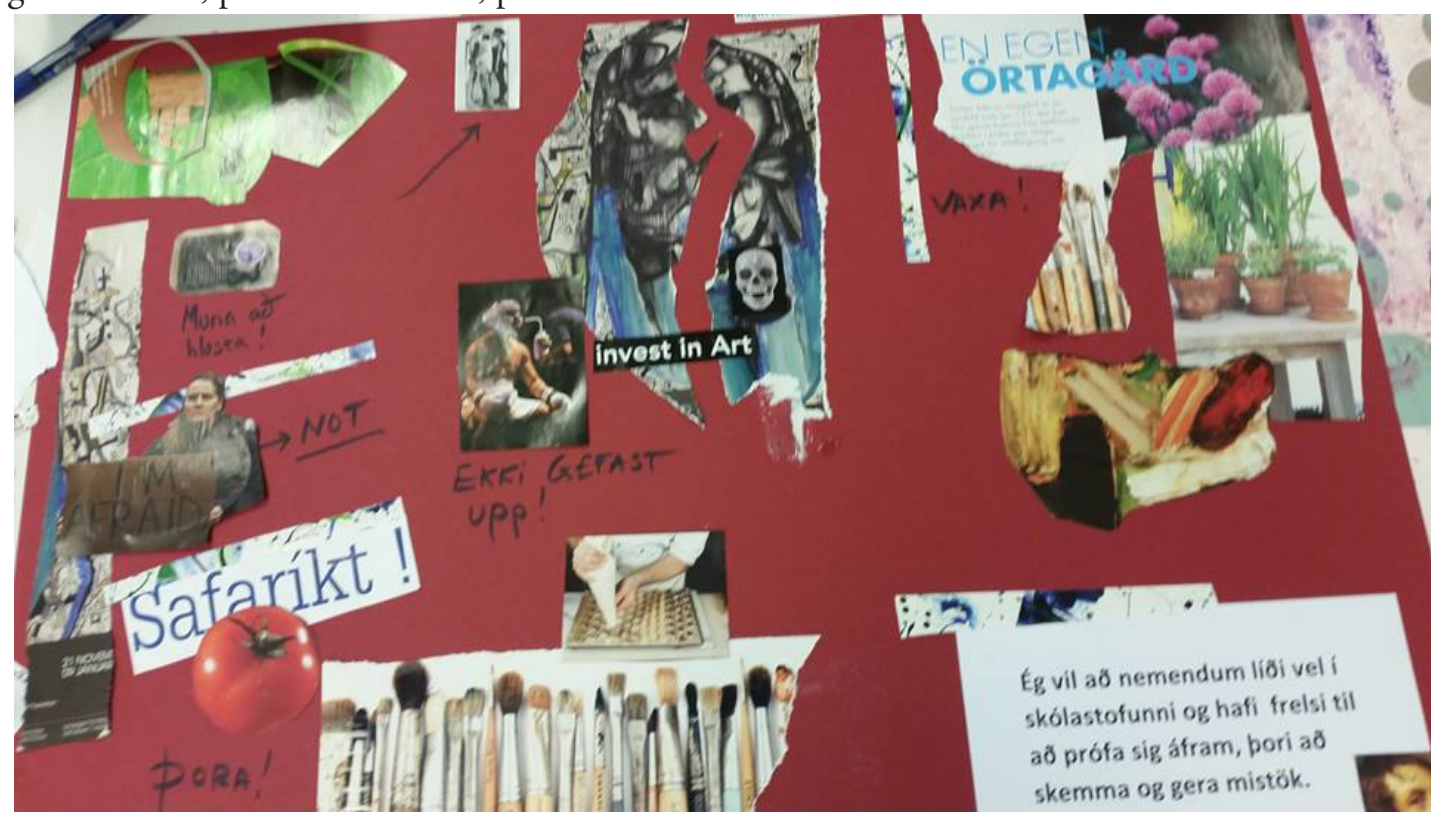

Mynd 2. Guðrún Halldóra veggspjald - starfskenning.

Guðrún Halldóra lýsti starfskenningu sinni og veggspjaldi (mynd 2) pannig að henni pætti mikilvægt að nemendur hennar kynntust sköpunarferlinu í myndlist. Hún sagðist gæta pess að peir fyndu fyrir öryggi og frelsi í skólastofunni, að hún væri uppörvandi og dæmdi ekki fyrir mistök. Hún sagði að pað að hlúa að nemendum væri „... svolítið eins og að rækta blóm og horfa á pau vaxa, hvert á sínum hraða og á ólíkan hátt“. Henni fyndist mikilvægt að nemendur upplifðu sig sem listamenn og að peim væri sýnd virðing:

Allir nemendur eru efni í listamenn, peir fá í hendurnar alvöru hráefni og verk peirra eru alvöru listaverk. Við breytum skólastofunni í vinnustofu og nemendur læra smám saman að ganga sjálf beint til verks án pess að bíða eftir fyrirmælum kennarans.

Sköpunarferlið getur verið erfitt og sársaukafullt en líka fullt af gleði og hamingju. Ég er sjálf menntaður myndlistarmaður og geng út frá pví að nemendur mínir muni í framtíðinni starfa á vettvangi myndlistar eða geti tekið pátt í myndlistarheiminum.

Með pessari sjónrænu tjáningu, og samtali myndmáls og talaðs máls, náði Guðrún Halldóra að draga fram mikilvæg atriði í sinni starfskenningu. Kjarnaatriði í hennar starfskenningu er að leitast við að sjá til pess að nemendur upplifi sig sem efni í listamenn, kynnist sköpunarferlinu og upplifi að pað geti bæði verið erfitt en líka fullt af gleði og hamingju.

Guðrún Gísladóttir myndlistarkennari sagðist nota fjölbreyttar aðferðir í kennslu sinni, meðal annars rafrænar leiðir. "Já, ég hef notað kennslumyndbönd af netinu og glærusýningar alls konar sem ég bý til, pví pað er lítið kennsluefni til í myndmennt." Hún sagðist gjarnan beita margvíslegum aðferðum: „Blanda af alls konar aðferðum, sýnikennsla, myndbönd, svo bara að prófa, tilraunir nota ég mikið. Prófa að gera eitthvað og sjá hvernig pað virkar eða kemur út." Hún lýsti hvað henni fyndist mikilvægt í kennslunni og hvaða merki hún sæi um að pað heppnaðist sem hún stefndi að: 
Pegar pau útfæra einhverja hugmynd eða verkefni, pegar hver og einn getur sett sitt handbragð á pað og útfært pað út frá sjálfum sér og ná að klára verkefnið og halda á pví og horfa á pað og geta sagt: „Já, ég gerði petta.“ Pá eru pau glöð. Eru ánægð með verkið sitt.

Henni, eins og fleirum, finnst erfitt að eiga við nemendur sem eru daufir og með lítið sjálfstraust. Henni finnst líka mikilvægt að próa sig í starfi, prófa nýjar leiðir og rýna í eigin kennslu. Hún finnur fyrir hömlum í pröngum tímaramma stundaskrárinnar og myndi vilja hafa sveigjanleika eins og opnir smiðjutímar gætu boðið upp á en tímarammaskorðurnar geri pað að verkum að henni finnst hún oft vera eins og „hamstur í hjóli“:

Pannig að ég held að maður verði aldrei útlærður í pessu starf. Maður er að bæta sig sem handverksmaður eða listamaður en líka að skoða hugmyndafræði eigin kennslu og allt svoleiðis.

Starfið er í rosalega föstum skorðum, maður er mikið á hlaupum til að halda tímaáætlun. Mér finnst stundum eins og ég sé hamstur í hjóli. Og maður verður rosalega lúinn pegar maður er búinn að vera í pessu hjóli lengi. En ég veit ekki hvernig hægt er að breyta pessu ... maður er soldill præll stundatöflunnar.

Guðrún Gísladóttir greindi pað úr sínum gögnum hvað hún gæti gert til að ýta undir skapandi vinnubrögð og hvernig hún gæfi nemendum tækifæri til að vinna út frá eigin veruleika. Hún sagðist líka vilja vera kennari með opinn huga, opinn fyrir hugmyndum nemenda og gefa peim tækifæri til persónulegrar túlkunar á viðfangsefnum. Hún sagðist leggja áherslu á að kennslustofan væri rík af efniviði „... sem kveikir á ímyndunarafli nemenda og hvetur til skapandi flæðis“.

Erla Dís textílkennari dró fram sem hluta af sinni starfskenningu ýmsa pætti sem henni eru mikilvægir og hún leggur áherslu á í kennslunni. Hún sagðist leggja áherslu á að nemendur hennar lærðu tæknina sem til pyrfti í verkefnum og færi ýmsar leiðir til pess, svo sem að vera með stuttar kynningar sem kveikjur, sýna listaverk og að láta nemendur vinna í teymum. Hún lýsti hvað henni fyndist mikill ávinningur pegar nemendur næðu tökum á tiltekinni tækni og aðferðum:

Pað er náttúrlega fátt sem gerir mig stoltari heldur en pegar nemendur ná tökum á tækni sem ég er að kenna peim. Pau eru svo glöð af pví að pau voru alveg viss um að pau gætu petta ekki. Pað er líka gaman að vera búin að sýna peim að pau geta miklu meira en pau halda.

Erla Dís sagðist vera í samstarfi við aðra kennara í skólanum og vera að vinna í alls konar teymum: „Раð gengur bara mjög vel allt samstarf, mjög vandað fólk og gott fólk sem ég vinn með." Hún kallaði pó eftir betri vinnuaðstæðum við textílkennsluna: „Ég myndi vilja bara vinna við betri kost, ég myndi vilja hafa stofuna mína betri og nútímalegri." Hún sagði pað vera pað eina sem hún hefði út á að setja en „... annars bara, hlakka ég til í að vaxa í pessu starfi“.

Metnaðurinn fyrir hönd greinarinnar og stoltið af pví að vinna starfið af fagmennsku og alúð var greinilegt í öllu pví sem Erla Dís deildi með okkur. Allir kennararnir sem tóku pátt í rannsókninni áttu pað sameiginlegt að hafa metnað fyrir hönd sinnar greinar en mátu sköpunarpáttinn líka mikils. Peir töldu allir að rannsóknarferlið hefði dýpkað skilning sinn á hvernig peir vinna og hvernig starfskenningu peir byggja á. Peim fannst ferlið hafa eflt sig sem fagmenn í kennslu.

\section{Umræður og ályktanir}

Kennsla sem eflir sköpunarhæfni nemenda hefur löngum pótt tilheyra list- og verkgreinum og pví mátti ætla að kennarar í pessum greinum hefðu ýmislegt fram að færa um eflingu sköpunarhæfni. Kennararnir sem ég hafði pann heiður að vinna með stóðu undir peim væntingum. 


\section{Mótun menningar skapandi náms}

Í niðurstöðunum mátti sjá viðleitni kennaranna við að móta menningu sem styður við skapandi nám. Einkenni skapandi kennslu og kennslu til sköpunar sem komu fram í gögnum rannsóknarinnar voru að losa um umgerð valinna pátta, pora að gera tilraunir sjálfir og hvetja nemendur einnig til hins sama, nota góðar kveikjur, eiga með nemendum skapandi samtöl og hvetja pá til hins sama.

Eitt af pví sem kennararnir rýndu í rannsóknarferlinu var umgerð eins og Bernstein (2000) skilgreinir hana. Peirra eigin greining og greining á gögnum úr rannsókninni sýndu að peir halda fast utan um ákveðna pætti eins og að vinna út frá pví sem peir telja mikilvægt úr námsgreininni og hvaða viðfangsefni er unnið með. Peir leitast hins vegar við að losa um stýringu á öðrum páttum eins og hraða, staðsetningu vinnu, vali á efnum og próun hugmynda og láta hana meira í hendur nemenda. Námsmati var ýmist stjórnað af kennaranum en stundum samtal og samkomulag milli kennarans og nemenda. Pannig mátti sjá kennarana feta jafnvægislist milli pess að veita nemendum frelsi til sköpunar og hins vegar stýringar og stjórnunar sem peir töldu óhjákvæmilega vegna námskrárkrafna og mikilvægis námsgreinarinnar sjálfrar.

Margir af sameiginlegum áherslupáttum kennaranna eru í anda nemendamiðaðrar kennslu en pað er nálgun sem talin er styðja við skapandi vinnubrögð (Ásta Henriksen, 2018; Lucas o.fl., 2013; OECD, 2019). Notkun stafrænna miðla til að styðja við sköpun nemenda var einn af páttunum sem ríma við nútímalega og skapandi kennsluhætti (Chang o.fl., 2019; Sigrún Björk Cortes o.fl., 2016; Sólveig Jakobsdóttir o.fl., 2019). Stíf umgerð á ákveðnum páttum kennslunnar virtist ekki ráðast af pví að kennararnir óttuðust óreiðuna (Svanborg R. Jónsdóttir og M. Allyson Macdonald, 2019), frekar var hún vegna námsgreinarinnar og krafna námskrárinnar um að koma til skila ákveðinni pekkingu og pjálfa tiltekin grunnvinnubrögð.

\section{Starfskenning og fagmennska}

Kennararnir leituðust við að finna leiðir til að uppfylla markmið námskrárinnar og finna jafnvægi milli frelsis til sköpunar og hæfniviðmiða um annars konar færni en sköpun. Eitt af pví sem peir gerðu til að efla eigin hæfni til að vinna petta krefjandi starf var að taka pátt í rannsókninni og með pví efla fagmennsku sína. Með pátttöku í pessari rannsókn á sínu eigin starfi sýndu kennararnir metnað fyrir hönd greinarinnar og kennarastarfsins. Pannig leiddu peir í ljós hvernig bæði er hægt að vinna ákveðin verkefni eins og „ríkisbangsann“ á skapandi hátt og um leið gæta pess að uppfylla kröfur aðalnámskrár. Peir drógu starfskenningu sína markvisst fram í rannsóknarferlinu, gerðu sér grein fyrir vali sínu á aðferðum í kennslu og hvernig peir fara að pví að efla sköpun nemenda sinna (Dalmau og Hafdís Guðjónsdóttir, 2017). Sú faglega ígrundun sem fram fór í ferlinu veitti peim dýpri skilning og studdi pá til að greina starfskenningu sína (Loughran, 2002; Svanborg R. Jónsdóttir, 2017). Pessir list- og verkgreinakennarar geta verið öðrum fyrirmyndir um skapandi kennsluhætti og um hvernig hægt er að draga fram í dagsljósið ýmsa áhrifapætti sem stýra kennurum beint og óbeint, meðal annars með pví að átta sig á starfskenningu sinni.

\section{How can the "state bear become a quaint artifact"? Arts and vocational teachers at three school levels share narratives from their action research}

The importance of creative thinking that can be parlayed into action is clear in the calls of modern societies for innovation, and the creative industries are seen as important in modern work life. Sustainable development also requires creative thinking and action competence in order to solve problems and meet the complex and multiple needs of the world. This paper describes an action research project that ran from autumn 2016 until autumn 2018, focusing on creativity in teaching and learning. I, the first author, led the action research of eight arts and vocational teachers at three school levels. The teachers were three arts teachers, two textile teachers, two IT and vocational subjects (in 
Icelandic, verkgreinar) teachers, and one drama teacher. On the teachers' behalf and in collaboration with them, I analysed the data and wrote the article with the support of a critical friend (the second author) who also participated in certain aspects of the research process. In this article we describe and analyse how the arts and vocational teachers sought to understand how they worked to enhance student creativity.

Data included journals, reflective notes, teaching plans, photographs, student information and transcriptions from research group meetings. The participants met monthly for two hours over each academic year, and the discussions and stories they shared were recorded and transcribed. Each teacher interviewed one other to identify and analyse what kind of teachers they aspired to be. At one meeting they made a collage to exemplify what they considered their professional working theory, and they also described the collage in words. In addition, they conducted an analytical exercise where they identified what kind of control they applied in a chosen part of their teaching, using Bernstein's (2000) concepts of framing and classification. These exercises and interviews helped to shed a light on the teachers' professional working theories and how they mastered the balancing act between strong and weak framing.

The data analysis is grounded in narrative inquiry, and the findings are presented through the teachers' narratives. Using the different methods in the research process and exercises to understand their teaching, such as applying Bernstein's concepts, interviewing and artistic approaches (collages), supported the teachers in reaching deeper and sharpening their focus on their practice and the spaces of learning they designed for their students. The findings were organized in two main categories: developing the culture of creative learning, and professional working theories and professionalism in teaching. Several themes were analysed in each category, and we show how they are exemplified in the teachers' narratives.

The Icelandic curricula from 2011 identify creativity as one of six fundamental ideals meant to be the foundation for all education from preschool to upper secondary schools. This explicit incorporation of creativity into the national curriculum gave industrial arts teachers an opportunity to rethink their instructional methods. The teachers in this study identified elements such as instructions from the curriculum that set certain limits on freedom, but they also strived for a balance between teacher control (strong framing) and giving students agency and freedom (weak framing). The culture the teachers sought to develop was characterized by teaching foundational work methods, mixed with freedom and creativity, chosen "sparks", experimentation, and creative conversations. By taking part in the research, the teachers showed professionalism and ambition on behalf of their subject and the teaching profession. They showed how it is possible to actualize projects such as the traditional task one of the textile teachers called the "state bear" in a creative and original way, "even quaint", while at the same time fulfilling the requirements of the state curriculum for training subject skills.

This article is dedicated to the memory of Erla Dís Arnardóttir textiles teacher who died long before her time in 2020. She was one of the teachers presented in this research and we miss her and remember her with gratitude.

Key words: Creativity, arts and vocational subjects, creative teaching, professional working theory, framing, agency, action research 


\section{Um höfunda}

Svanborg Rannveig Jónsdóttir (svanjons@hi.is) er prófessor við Menntavísindasvið Háskóla Íslands. Hún lauk B.Ed.-prófi frá Kennaraháskóla Íslands 1978 með íslensku og dönsku sem aðalgreinar. Hún lauk M.A.-prófi í uppeldis- og menntunarfræðum frá Háskóla Îslands 2005 með áherslu á nýsköpunarmennt. Árið 2011 lauk hún doktorsnámi frá Menntavísindasviði Háskóla Íslands og er titill doktorsritgerðar hennar The location of innovation education in Icelandic compulsory schools. Rannsóknir hennar snúast um nýsköpunar- og frumkvöðlamennt, námskrárfræði, skapandi skólastarf, breytingastarf og starfstengda sjálfsrýni í kennaramenntun.

Hafdís Guðjónsdóttir (hafdgud@hi.is) er prófessor við Menntavísindasvið Háskóla Íslands. Áður en hún hóf störf par kenndi hún í 26 ár við grunnskóla og sinnti bæði bekkjar- og sérkennslu. Rannsóknir hennar byggjast aðallega á eigindlegum rannsóknum, starfstengdri sjálfsrýni og starfendarannsóknum. Í rannsóknum sínum leggur húnáhersluá menntun án aðgreiningar, fjölmenningarlega kennslu, kennslufræði, starfspróun kennara og fagmennsku, en einnig á kennaramenntun og próun kennaramenntunarkennara.

\section{About the authors}

Svanborg Rannveig Jónsdóttir (svanjons@hi.is) is a professor at the University of Iceland School of Education (IUE). She completed a B.Ed. degree at the Iceland University of Education in 1978, an M.A. degree in pedagogy from the University of Iceland and a Ph.D. from the University of Iceland, School of Education in 2011. Her thesis is titled The location of innovation education in Icelandic compulsory schools. Her research fields are innovation-related and entrepreneurial education, curriculum development, creativity in education, school change and professional self-study in teacher education.

Hafdís Guðjónsdóttir (hafdgud@hi.is) is a professor at the University of Iceland School of Education (IUE). Before joining the university, she worked for 26 years as a general classroom teacher and special educator at compulsory school. Her research methodology is a qualitative and self-study investigation of education practices. Her research interests are in the area of inclusion and multicultural education, pedagogy and educational practices, teacher development and professionalism and teacher education.

Rannsóknin var styrkt af Rannsóknasjóði Háskóla Íslands

\section{Heimildir}

Anna Elísa Hreiðarsdóttir. (2019). Stafræn tækni í leikskólastarfi: Sjónarhorn frumkvöðla. Sérrit Netlu 2019 - Menntun barna í leikskóla og á yngsta stigi í grunnskóla. https://netla.hi.is/serrit/2019/menntun_barna_leik_grunn/08.pdf

Ágúst Einarsson. (2012). Menningarhagfraði. Háskólinn á Bifröst.

Ásta Henriksen. (2018). Sköpun skiptir sköpum: Viðhorf tungumálakennara til skapandi kennsluhátta. Sérrit Netlu 2018 - Frambaldsskólinn i brennidepli. https://netla.hi.is/serrit/2018/framhaldskolinn_brennidepli/08.pdf

Bernstein, B. (2000). Pedagogy, symbolic control, and identity (2. útgáfa). Rowman og Littlefield.

Blake, J., Sterling, S. og Goodson, I. (2013). Transformative learning for a sustainable future: An exploration of pedagogies for change at an alternative college. Sustainability, 5(12), 5347-5372. https://doi.org/10.3390/ su5125347

Chang, Y.-S., Chen, M.Y.-C., Chuang, M.-J. og Chou, C.-H. (2019). Improving creative self-efficacy and performance through computer-aided design application. Thinking Skills and Creativity, 31, 103-111. https:// doi.org/10.1016/j.tsc.2018.11.007 
Collard, P. og Looney, J. (2014). Nurturing creativity in education. European Journal of Education, 49(3), 348-364. https://doi.org/10.1111/ejed.12090

Connelly, F. M. og Clandinin, D. J. (1990). Stories of experience and narrative inquiry. Educational Researcher, 19(5), 2-14. https://doi.org/10.3102/0013189X019005002

Craft, A. (2000). Creativity across the primary curriculum: Framing and developing practice. Routledge.

Craft, A. (2001a). An analysis of research and literature on creativity in education. Qualifications and Curriculum Authority.

Craft, A. (2001b). Little c creativity. Í A. Craft, B. Jeffrey og M. Leibling (ritstjórar), Creativity in education (bls. 45-61). Continuum.

Craft, A., Cremin, T., Burnard, P. og Chappell, K. (2008). Possibility thinking with children aged 3-7 in England. I A. Craft, T. Cremin og P. Burnard (ritstjórar), Creative Learning 3-11 and how we document it (bls. 65-74). Trentham.

Craft, A., McConnon, L. og Paige-Smith, A. (2012). Child-initiated play and professional creativity: Enabling four-year-olds' possibility thinking. Thinking Skills and Creativity, 7(1), 48-61. https://doi.org/10.1016/j. tsc.2011.11.005

Dalmau, M. og Hafdís Guðjónsdóttir. (2017). From the beginning to the future: Professional working theory emerging. İ M. C. Dalmau, Hafdís Guðjónsdóttir og D. Tidwell (ritstjórar), Taking a fresh look at education: Framing professional learning in education through self-study (bls. 129-148). Sense.

Edda Kjartansdóttir. (2010). Starfendarannsóknir til valdeflingar: Með rannsóknum á eigin störfum geta kennarar öðlast vald yfir pekkingunni á fagi sínu. Ráðstefnurit Netlu-Menntakvika 2010. https://netla.hi.is/ serrit/2010/menntakvika2010/alm/007.pdf

Feldman, A. (2002). Existential approaches to action research. Educational Action Research, 10(2), $233-252$.

Hafdís Guðjónsdóttir. (2004). Kennarar ígrunda og rannsaka eigið starf. Tímarit um menntarannsóknir, 1, 27-38.

Hafdís Ingvarsdóttir. (2004). Mótun starfskenninga íslenskra framhaldsskólakennara. Tímarit um menntarannsóknir, 1, 39-47.

Hafpór Guðjónsson. (2011). Kennarinn sem rannsakandi. Rádstefnurit Netlu-Menntakvika 2011. https:// netla.hi.is/serrit/2011/menntakvika2011/011.pdf

Handal, G. og Lauvås, P. (1987). Promoting reflective teaching: Supervision in action. Open University Press.

Hrafnhildur Eiðsdóttir og Jóhanna Einarsdóttir. (2013). Sköpunarkraftur og sköpunarferli í skólastarfi. Sérrit Netlu 2013 - Fagið og freðin. https://netla.hi.is/serrit/2013/fagid_og_fraedin/004.pdf

Ingibjörg Jóhannsdóttir, Elísabet Indra Ragnarsdóttir og Torfi Hjartarson. (2012). Sköpun: Grunnpáttur menntunar á öllum skólastigum. Mennta- og menningarmálaráðuneytið.

Jeffrey, B. og Craft, A. (2006). Creative learning and possibility thinking. Í B. Jeffrey (ritstjóri), Creative learning practices: European experiences (bls. 47-62). Tufnell Press.

Kim, J.-H. (2015). Understanding narrative inquiry: The crafting and analysis of stories as research. SAGE.

Kristín Dýrfjörð, Torfi Hjartarson, Anna Elísa Hreiðarsdóttir, Sólveig Jakobsdóttir, Svanborg R. Jónsdóttir, Skúlína Hlíf Kjartansdóttir, Margrét E. Ólafsdóttir, Svava Pétursdóttir og Gísli Porsteinsson. (2019). Makerspaces in formal and non-formal learning contexts in Iceland. Í A. Blum-Ross, K. Kumpulainen og J. Marsh (ritstjórar), Enhancing digital literacy and creativity: Makerspaces in the early years (bls. 71-91). Routledge.

Lilja M. Jónsdóttir. (2012). „Pað er náttúrulega ekki hægt að kenna manni allt“: Viðhorf byrjenda í grunnskólakennslu til kennaranáms síns. Netla - Veftimarit um uppeldi og menntun. https://netla.hi.is/greinar/2012/ ryn/005.pdf

Loughran, J. (2002). Effective reflective practice: In search of meaning in learning about teaching. Journal of Teacher Education 53(1), 33-43. https://doi.org/10.1177/0022487102053001004

Lucas, B., Claxton, G. og Spencer, E. (2013). Progression in student creativity in school: First steps towards new forms of formative assessments. OECD Education working Papers No. 86. https://doi.org/10.1787/5k4dp59msdwk-en

McNiff, J. (2017). Action research: All you need to know. SAGE. 
McNiff, J., Lomax, P. og Whitehead, J. (2003). You and your action research project. Routledge/Falmer.

Mennta- og menningarmálaráduneyti. (2012). Aðalnámskrá grunnskóla 2011: Almennur hluti.

NACCCE. (1999). All our futures: Creativity, culture and education. Department for Education and Employment.

Nýsköpun á Íslandi: Kynningarblað. (2018, 4. júlí). Fréttablaðið. https://www.si.is/media/_eplica-uppsetning/ nyskopun-kynning-frettabladid-04-07-2018.pdf

OECD. (2019). PISA 2021 creative thinking framework (3. drög). https://www.oecd.org/pisa/publications/ PISA-2021-creative-thinking-framework.pdf

Sigríður Ólafsdóttir, Rannveig Björk Porkelsdóttir og Hanna Ólafsdóttir. (2018). Sköpun í stafrænum heimi: Sjónarmið myndmenntakennara. Netla - Veftimarit um uppeldi og menntun. https://netla.hi.is/greinar/2018/ ryn/12.pdf

Sigrún Björk Cortes, Björgvin Ívar Guðbrandsson, Margrét Hugadóttir og Torfi Hjartarson. (2016). Skapandi skóli: Handbók um fölbreytta kennsluhatti og stafrana miðlun. Menntamálastofnun.

Sólveig Jakobsdóttir, Kristín Dýrfjörð, Skúlína Hlíf Kjartansdóttir, Svanborg R. Jónsdóttir og Svava Pétursdóttir. (2019). Sköpunarsmiðjur í menntun ungra barna: Reynsla og viðhorf starfsfólks skóla, safna og sköpunarsmiðja. Sérrit Netlu 2019 - Menntun barna i leikskóla og á yngsta stigi i grunnskóla. https://netla. hi.is/serrit/2019/menntun_barna_leik_grunn/09.pdf

Sternberg, R. J. og Lubart, T. I. (1999). The concept of creativity: Prospects and paradigms. Í R. J. Sternberg (ritstjóri), Handbook of creativity (bls. 3-15). Cambridge University Press.

Stringer, E. T. (2007). Action research (3. útgáfa). SAGE.

Svanborg R. Jónsdóttir. (2011). The location of innovation education in Icelandic compulsory schools (doktorsritgerð, Háskóli Íslands). http://hdl.handle.net/1946/7766

Svanborg R. Jónsdóttir. (2017). Narratives of creativity: How eight teachers on four school levels integrate creativity into teaching and learning. Thinking Skills and Creativity, 24, 127-139. https://doi.org/10.1016/j. tsc.2017.02.008

Svanborg R. Jónsdóttir og M. Allyson Macdonald. (2019). The feasibility of innovation and entrepreneurial education in middle schools. Journal of Small Business and Enterprise Development, 26(2), 255-272. https:// doi.org/10.1108/JSBED-08-2018-0251

Svanborg R. Jónsdóttir og Rósa Gunnarsdóttir. (2017). The road to independence: Emancipatory pedagogy. Sense.

Tierney, P. og Farmer, S. M. (2011). Creative self-efficacy development and creative performance over time. Journal of Applied Psychology, 96(2), 277-293. https://doi.org/10.1037/a0020952

Zeichner, K. M. (1993). Action research: Personal renewal and social reconstruction. Educational Action Research, 1(2), 199-219. https://doi.org/10.1080/0965079930010202

Svanborg R. Jónsdóttir og Hafdís Guðjónsdóttir. (2021).

Hvernig verður „ríkisbangsinn flippaður“? List- og verkgreinakennarar á premur skólastigum segja rýnisögur úr starfendarannsóknum sínum.

Netla - Veftímarit um uppeldi og menntun. Menntavísindasvið Háskóla Íslands.

Sótt af https://netla.hi.is/greinar/2021/alm/04.pdf

DOI: https://doi.org/10.24270/netla.2021.4 